\title{
Variation of the radiative properties during black carbon aging: theoretical and experimental intercomparison
}

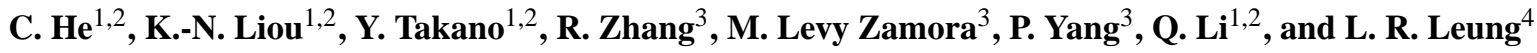 \\ ${ }^{1}$ Department of Atmospheric and Oceanic Sciences, University of California, Los Angeles (UCLA), CA 90095, USA \\ ${ }^{2}$ Joint Institute for Regional Earth System Science and Engineering, University of California, Los Angeles (UCLA), \\ CA 90095, USA \\ ${ }^{3}$ Department of Atmospheric Sciences, Texas A\&M, College Station, TX 77845, USA \\ ${ }^{4}$ Pacific Northwest National Laboratory, Richland, WA 99352, USA \\ Correspondence to: C. He (cenlinhe@atmos.ucla.edu)
}

Received: 8 June 2015 - Published in Atmos. Chem. Phys. Discuss.: 20 July 2015

Revised: 3 October 2015 - Accepted: 20 October 2015 - Published: 28 October 2015

\begin{abstract}
A theoretical black carbon (BC) aging model is developed to account for three typical evolution stages, namely, freshly emitted aggregates, BC coated by soluble material, and $\mathrm{BC}$ particles undergoing further hygroscopic growth. The geometric-optics surface-wave (GOS) approach is employed to compute the $\mathrm{BC}$ single-scattering properties at each aging stage, which are subsequently compared with laboratory measurements. Theoretical calculations are consistent with measurements in extinction and absorption cross sections for fresh BC aggregates with different BC sizes (i.e., mobility diameters of 155,245 , and $320 \mathrm{~nm}$ ), with differences of $\leq 25 \%$. The measured optical cross sections for BC coated by sulfuric acid and for that undergoing further hygroscopic growth are generally captured (differences $<30 \%$ ) by theoretical calculations using a concentric core-shell structure, with an overestimate in extinction and absorption of the smallest $\mathrm{BC}$ size and an underestimate in scattering of the largest $\mathrm{BC}$ size. We find that the absorption and scattering cross sections of fresh BC aggregates vary by $20-40$ and 50$65 \%$, respectively, due to the use of upper (1.95-0.79i) and lower $(1.75-0.63 i)$ bounds of $\mathrm{BC}$ refractive index, while the variations are $<20 \%$ in absorption and $<50 \%$ in scattering in the case of coated BC particles. Sensitivity analyses of the $\mathrm{BC}$ morphology show that the optical properties of fresh $\mathrm{BC}$ aggregates are more sensitive to fractal dimension than primary spherule size. The absorption and scattering cross sections of coated BC particles vary by more than a factor of 2 due to different coating structures. We find an increase of $20-250 \%$ in absorption and a factor of 3-15 in scattering
\end{abstract}

during aging, significantly depending on coating morphology and aging stages. This study suggests that an accurate estimate of $\mathrm{BC}$ radiative effects requires the incorporation of a dynamic $\mathrm{BC}$ aging process that accounts for realistic coating structures in climate models.

\section{Introduction}

Black carbon (BC) has been identified as the second most important anthropogenic global warming agent in the atmosphere by virtue of its strong absorption of solar radiation and its role as cloud condensation nuclei (CCN) in cloud formation (Ramanathan and Carmichael, 2008; Bond et al., 2013; Wang et al., 2013; Jacobson, 2014). BC climatic effects are significantly influenced by the $\mathrm{BC}$ aging process in the atmosphere, which transforms BC from an external to internal mixing state (Schwarz et al., 2008; China et al., 2013) and increases its hygroscopicity (Zhang et al., 2008; Popovicheva et al., 2011) and light absorption (Jacobson, 2001; Shiraiwa et al., 2010; Qiu et al., 2012; Scarnato et al., 2013).

Freshly emitted BC particles are mostly hydrophobic and externally mixed with other aerosol constituents (Zuberi et al., 2005; Zhang et al., 2008). BC agglomerates shortly after emission to form irregular aggregates because of multi-phase processes (Zhang et al., 2008; Pagels et al., 2009; Xue et al., 2009). Early studies have found that BC particles age in the atmosphere through condensation and coagulation processes (e.g., Heintzenberg and Covert, 1984; Heintzenberg, 1989). 
Recent studies have confirmed that $\mathrm{BC}$ becomes coated by water-soluble material during atmospheric aging, including condensation of sulfate, nitrate, and organics (Moteki et al., 2007; Shiraiwa et al., 2007), coagulation with preexisting aerosols (Johnson et al., 2005; Kondo et al., 2011), and heterogeneous reactions with gaseous oxidants (Zuberi et al., 2005; Khalizov et al., 2010; Zhang et al., 2012). At the same time, BC aggregates also exhibit considerable restructuring and compaction (Weingartner et al., 1997; Saathoff et al., 2003; Zhang et al., 2008), which significantly alters BC morphology (Adachi and Buseck, 2013; China et al., 2015). Aged BC particles experience hygroscopic growth and activate efficiently as CCN (Zuberi et al., 2005; Zhang et al., 2008). The hygroscopic growth of BC particles depends on their initial size, condensed soluble material mass, surface chemical property, and ambient relative humidity (RH) (Zhang et al., 2008; Khalizov et al., 2009b; Popovicheva et al., 2011).

A number of laboratory experiments have been conducted to investigate the effects of atmospheric aging on $\mathrm{BC}$ radiative properties. Gangl et al. (2008) showed that internal $\mathrm{BC}-$ wax mixture amplifies the $\mathrm{BC}$ absorption coefficient by 10-90\%, depending on the amount of coating. Shiraiwa et al. (2010) found that BC absorption enhancement due to organic coating varies significantly for various BC sizes and coating thickness, with up to a factor of 2 enhancement for thick coatings. Under different experimental conditions, relatively small increases $(\sim 30 \%)$ in $\mathrm{BC}$ absorption have also been observed for BC coated by sulfuric acid (Zhang et al., 2008) and some organics (Saathoff et al., 2003). Furthermore, Xue et al. (2009) and Qiu et al. (2012) showed a less than $20 \%$ increase in BC absorption for organic coating, which depends on organic species and coating thickness. Thus, the resulting large variation among different experimental studies indicates that the aging effects on $\mathrm{BC}$ radiative properties strongly depend on coating material and thickness as well as BC particle size. It is clear, therefore, that experimental details are critically important in making meaningful and appropriate comparisons among various experimental studies involving BC absorption enhancement associated with coating.

Field measurements have also revealed substantial variation in BC optical properties during atmospheric aging. Bond and Bergstrom (2006) showed that observed BC mass absorption cross sections (MAC) vary by more than a factor of 2 (mostly $5-13 \mathrm{~m}^{2} \mathrm{~g}^{-1}$ ) under different atmospheric conditions. Based on direct measurements at a suburban site in Japan, Naoe et al. (2009) showed that coating increases BC absorption by a factor of 1.1-1.4 with a larger increase for thicker coatings. Knox et al. (2009) found an absorption enhancement of up to $45 \%$ due to BC coating based on measurements in downtown Toronto. Similar increases in absorption have also been directly observed for the internal mixing of biomass-burning BC (Lack et al., 2012). However, Cappa et al. (2012) reported that the observed BC absorption in- creased only by $6 \%$ due to internal mixing based on direct in situ measurements over California. This suggests that coating effects on $\mathrm{BC}$ absorption are rather complex in reality, which depends on different coating material, mass, and structure influenced by emission sources and atmospheric processes.

Adachi et al. (2010) found that many BC particles embedded within host material are chainlike aggregates locating in off-center positions, based on transmission electron microscope (TEM) observations for samples collected from Mexico City. Using the discrete dipole approximation (DDA) method developed by Draine and Flatau (1994), Adachi et al. showed that a more realistic BC coating morphology results in 20-40\% less absorption at visible wavelengths than a concentric core-shell shape. Based on ground-based measurements during the California Research at the Nexus of Air Quality and Climate Change (CalNex) campaign, Adachi and Buseck (2013) further observed that many BC particles are only attached to host material instead of being fully embedded within them, leading to only a slight increase in BC absorption. They concluded that the complex mixing structure of BC particles could explain a smaller absorption amplification by $\mathrm{BC}$ coating determined from observations than the results computed from an idealized core-shell model. China et al. $(2013,2015)$ classified the observed irregular BC coating shapes into four types: embedded (heavily coated), thinly coated, partly coated, and partially encapsulated. These complex coating structures substantially affect BC optical properties (e.g., Videen et al., 1994; Liu and Mishchenko, 2007; Kahnert et al., 2013), which is one of the most important uncertainty sources in evaluating $\mathrm{BC}$ direct radiative forcing (DRF) (Bond et al., 2013). Thus, a reliable estimate of BC DRF requires a quantitative understanding of the evolution of $\mathrm{BC}$ radiative properties under the influence of various morphology during atmospheric aging.

In this study, we have developed a theoretical $\mathrm{BC}$ aging model based on the current understanding of the $\mathrm{BC}$ aging process, which accounts for three major stages, namely, freshly emitted aggregates, BC coated by soluble material, and $\mathrm{BC}$ particles undergoing further hygroscopic growth. We apply the geometric-optics surface-wave (GOS) approach to compute light absorption and scattering of $\mathrm{BC}$ particles at each aging stage. The theoretical calculations are compared with laboratory measurements, followed by a systematic evaluation of uncertainties associated with BC morphology and refractive index. Finally, we discuss the implication of model results for $\mathrm{BC}$ radiative effect assessment.

\section{Methods}

\subsection{A theoretical $\mathrm{BC}$ aging model}

Based on the current knowledge of BC atmospheric aging, we have developed a theoretical model accounting for three major BC aging stages, as depicted in Fig. 1. Stage I repre- 
sents freshly emitted BC aggregates that are externally mixed with other particles. Stage II represents BC particles coated by water-soluble aerosol constituents through condensation, coagulation, and/or heterogeneous oxidations. Stage III represents BC particles coated by both soluble material and water through hygroscopic growth. In this study, six typical BC coating structures (Fig. 1) have been considered for Stages II and III to approximately represent observations in the real atmosphere or laboratory, including embedded (i.e., concentric core-cell, off-center core-shell, and closed-cell), partially encapsulated, and partly coated (i.e., open-cell and externally attached) structures following the classification presented in China et al. $(2013,2015)$. The concentric and off-center coreshell structures (Martins et al., 1998; Sedlacek et al., 2012) are a result of considerable collapse of $\mathrm{BC}$ aggregates into more compact and spherical clusters when fully engulfed in coating material (Zhang et al., 2008). The closed-cell structure is an example of where coating material not only covers the outer layers of BC aggregates but also fills the internal voids among primary spherules (Strawa et al., 1999). The partially encapsulated structure is formed when only a part of BC aggregate merges inside coating material (China et al., 2015). The open-cell and externally attached structures are produced by coating material sticking to a part of BC aggregates' surface (Stratmann et al., 2010; China et al., 2015). We wish to note that the six coating structures used in this study, including closed-cell and open-cell structures, are theoretical models and as such, they may not completely capture detailed BC coating structures from aircraft and ground-based observations. Further hygroscopic growth of BC particles after Stage III could lead to the formation of cloud droplets, a subject beyond the scope of the present study.

\subsection{Laboratory measurements}

The physical and radiative properties of $\mathrm{BC}$ particles during aging after exposure to sulfuric acid $\left(\mathrm{H}_{2} \mathrm{SO}_{4}\right)$ under various RH conditions (5-80\%) have been measured in the laboratory by Zhang et al. (2008) and Khalizov et al. (2009a). $\mathrm{BC}$ aggregates were generated by incomplete combustion of propane in a laminar diffusion burner (Santoro et al., 1983) and were sampled by a pinhole diluter (Kasper et al., 1997). A tandem differential mobility analyzer (TDMA) system was used to produce singly charged mobility-classified $\mathrm{BC}$ particles, followed by a coating chamber with controlled $\mathrm{RH}$ and $\mathrm{H}_{2} \mathrm{SO}_{4}$ vapor concentrations at room temperatures $(299 \pm 1 \mathrm{~K})$. The $\mathrm{BC}$ mass and size growth due to $\mathrm{H}_{2} \mathrm{SO}_{4}$ and water vapor $\left(\mathrm{H}_{2} \mathrm{O}\right)$ condensation during aging were measured by an aerosol particle mass (APM) analyzer and TDMA, respectively. The effective density and fractal dimension $\left(D_{\mathrm{f}}\right)$ of BC particles were derived from the measured $\mathrm{BC}$ mobility diameter $\left(D_{\mathrm{BC}}\right)$ and mass (see Eqs. 1 and 2 in Zhang et al., 2008). The compaction and restructuring of BC aggregates were captured by a TEM (see Fig. 1 in Zhang et al., 2008). BC extinction and scattering cross sections were measured at $532 \mathrm{~nm}$ wavelength by a cavity ring-down spectrometer (CRDS) and an integrating nephelometer, respectively. The absorption cross section was determined from the resulting difference between extinction and scattering cross sections. Khalizov et al. (2009a) showed that uncertainty in measured optical cross sections of coated $\mathrm{BC}$ particles is within $10 \%$, which primarily represents uncertainty in relative humidity, particle size, number density, and instrument calibration. This uncertainty, however, does not include the contribution from multiply charged particles. For freshly emitted BC aggregates, measured scattering cross sections involve relatively large uncertainties. More details on laboratory experiments have been presented in Zhang et al. (2008) and Khalizov et al. (2009a). Three experimental cases with initial $D_{\mathrm{BC}}$ of 155,245 , and $320 \mathrm{~nm}$ were used in this study (see Table 1). In each case, $\mathrm{BC}$ particles exposed to $\mathrm{H}_{2} \mathrm{SO}_{4}$ vapor $\left(1.4 \times 10^{10}\right.$ molecules $\left.\mathrm{cm}^{-3}\right)$ at 5 and $80 \%$ RH were used to represent coated BC at Stages II and III (see Sect. 2.1), respectively.

\subsection{Geometric-optics surface-wave (GOS) approach}

We employed the GOS approach developed by Liou et al. (2011, 2014), which explicitly treats fractal aggregates and various coating structures, to compute absorption and scattering properties of $\mathrm{BC}$ particles at three aging stages. In the GOS approach, a stochastic procedure developed by Liou et al. (2011) is applied to simulate homogeneous aggregates and coated particles with different shapes in a 3-D coordinate system. In this study, we have extended the original stochastic process to generate more complex coating morphology, including the partially encapsulated and externally attached structures (see Figs. S1-S6 in the Supplement). Once the particle shape and composition are determined by the stochastic procedure, the reflection and refraction of particles are computed with the hit-and-miss Monte Carlo photon tracing technique. The extinction and absorption cross sections are derived following a ray-by-ray integration approach (Yang and Liou, 1997). Diffraction by randomly oriented nonspherical particles is computed on the basis of Babinet's principle (Born and Wolf, 1999) and photon-number-weighted geometric cross sections. The GOS approach accounts for the interaction of incident waves at grazing angles near the particle edge and propagating along the particle surface into shadow regions, referred to as the surface wave, using the formulation developed by Nussenzveig and Wiscombe (1980) for spheres as the basis for physical adjustments and application to nonspherical particles (Liou et al., 2010, 2011). The concept of the GOS approach is graphically displayed in Fig. 2 and it is designed for computations of absorption and extinction cross sections and asymmetry factors in line with experimental results.

Liou et al. (2010, 2011) and Takano et al. (2013) demonstrated that the single-scattering properties of aerosols with different sizes and shapes determined from the GOS ap- 

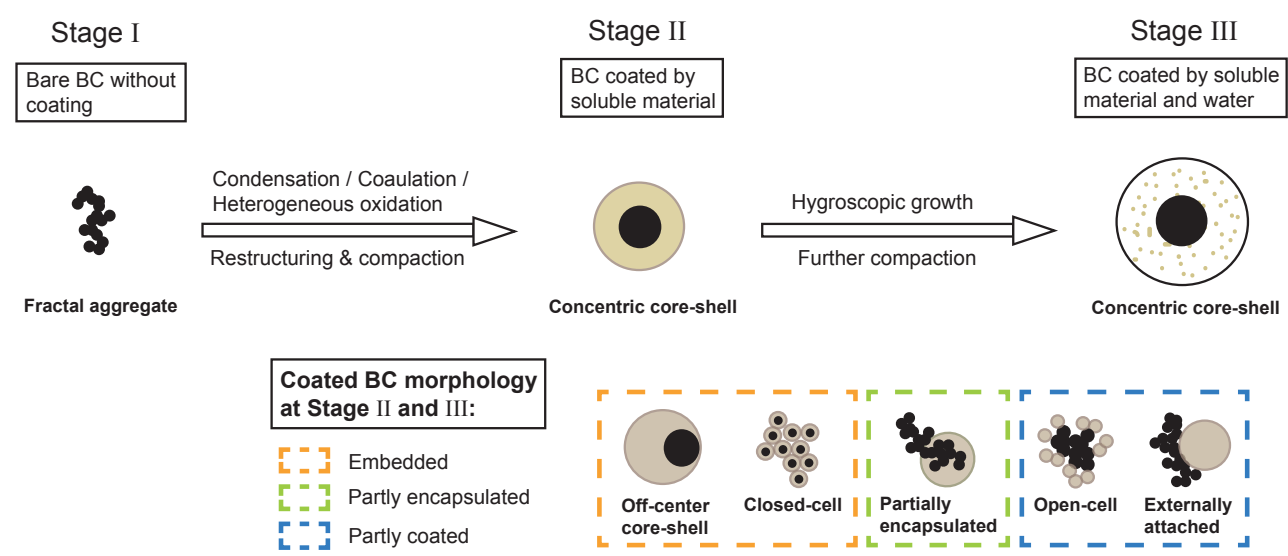

Figure 1. A theoretical model that accounts for three BC aging stages and the associated BC structures, including freshly emitted aggregates (Stage I), BC coated by soluble material (Stage II), and BC after further hygroscopic growth (Stage III). Six typical structures for coated BC at Stages II and III are considered based on atmospheric observations, including embedded (i.e., concentric core-shell, off-center core-shell, and closed-cell), partially encapsulated, and partly coated (i.e., open-cell and externally attached) structures. See text for details.

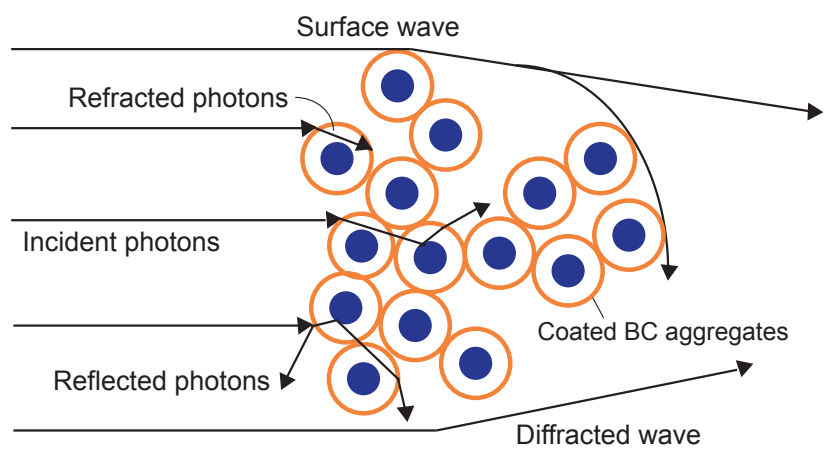

Figure 2. A graphical representation of the geometric-optics surface-wave (GOS) approach for light scattering and absorption by coated BC aggregates. The GOS components include the hit-andmiss Monte Carlo photon tracing associated with internal and external refractions and reflections, diffraction following Babinet's principle for randomly oriented irregular particles, and surface waves traveling along the particle edges and propagating into shadow regions. See text for details.

proach compare reasonably well (differences $<20 \%$ ) with those determined from the finite-difference time-domain (FDTD) method (Yang and Liou, 1996) and DDA (Draine and Flatau, 1994) for column and plate ice crystals, the superposition T-matrix method (Mackowski and Mishchenko, 1996) for fractal aggregates, and the Lorenz-Mie model (Toon and Ackerman, 1981) for a concentric core-shell shape. Moreover, compared with other numerical methods, the GOS approach can be applied to a wider range of particle sizes, shapes, and coating morphology with a high computational efficiency, including very large particles (e.g., $\sim 100$ $1000 \mu \mathrm{m}$ snowflakes) and complex multiple inclusions of aerosols within irregular snow grains (Liou et al., 2014; He et al., 2014), in which the FDTD, DDA, and T-matrix meth- ods have not been able to be applied. As stated previously, the GOS approach has been developed specifically for optical cross sections (i.e., extinction, absorption, and scattering) and the asymmetry factor. Also, due to the approximation in the use of geometric photon tracing, the GOS approach has limitation and uncertainty for application to size parameters much smaller than 1 . To supplement GOS, we have developed the Rayleigh-Gans-Debye (RGD) approximation coupled with GOS for very small particles, which has been cross-validated with the superposition $\mathbf{T}$-matrix method (Takano et al., 2013). Takano et al. (2013) showed that the coupled GOS-RGD and superposition T-matrix results are both close to the observed specific absorption of $\mathrm{BC}$ aggregates for the range of size parameter considered in the present study. The coupled GOS-RGD approach can be applied to size parameters covering 0.1 to 1000 . In the present study, the coupled GOS-RGD approach is used for fresh BC aggregates (Stage I), while the GOS approach without RGD coupling is used for coated BC particles (Stages II and III).

\subsection{Theoretical calculations}

We used BC physical properties measured from laboratory experiments (see Sect. 2.2) as input to theoretical calculations (see Table 1). In standard calculations, the freshly emitted $\mathrm{BC}$ aggregates (Stage I) were assumed to be comprised of primary spherules with a diameter $\left(D_{\mathrm{p}}\right)$ of $15 \mathrm{~nm}$ measured from the experiments and were constructed by the GOS stochastic procedure to reproduce the measured mass and fractal dimension (i.e., 2.1) of $\mathrm{BC}$ aggregates. The $\mathrm{BC}$ mass was the product of measured $\mathrm{BC}$ effective densities and mobility volumes. The mass of $\mathrm{H}_{2} \mathrm{SO}_{4}$ coating on $\mathrm{BC}$ at Stage II was derived from the observed relationship between condensed $\mathrm{H}_{2} \mathrm{SO}_{4}$ mass and particle diameter at $5 \% \mathrm{RH}$. The mass of $\mathrm{H}_{2} \mathrm{O}$ condensed on $\mathrm{H}_{2} \mathrm{SO}_{4}$-coated $\mathrm{BC}$ at Stage III 


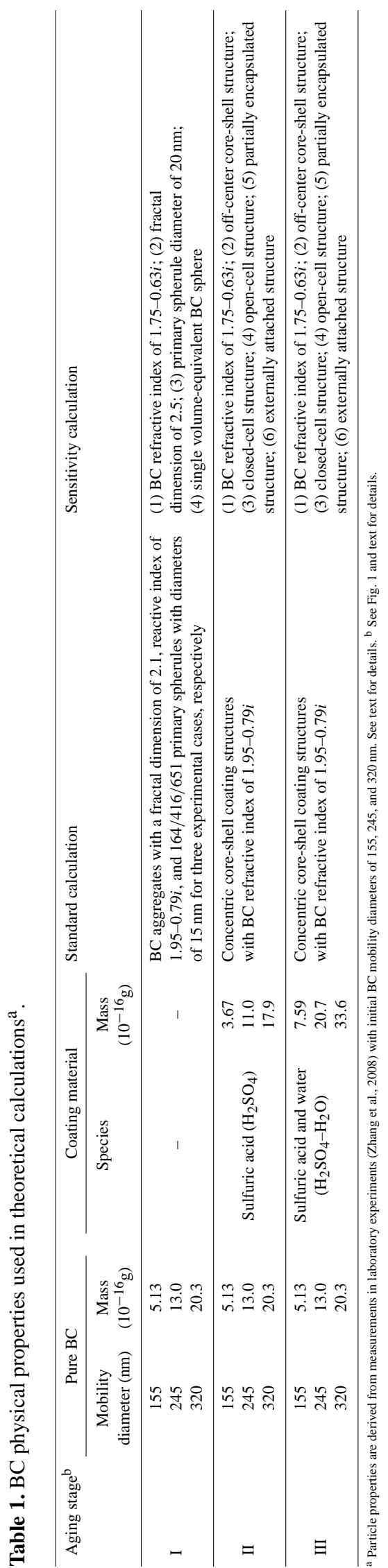

was derived from the measured hygroscopic mass growth ratio of $\mathrm{H}_{2} \mathrm{SO}_{4}$-coated $\mathrm{BC}$ at $80 \% \mathrm{RH}$. In standard calculations, we used a concentric core-shell structure for coated BC particles at Stages II and III because of the strong particle compaction during aging based on laboratory observations (Zhang et al., 2008). Thus, BC core size and coating thickness were computed from the mass of $\mathrm{BC}$ and $\mathrm{H}_{2} \mathrm{SO}_{4} / \mathrm{H}_{2} \mathrm{O}$ coating. The refractive index (RI) of $\mathrm{H}_{2} \mathrm{SO}_{4}-\mathrm{H}_{2} \mathrm{O}$ coating at Stage III was derived as the volume-weighted RI of $\mathrm{H}_{2} \mathrm{SO}_{4}$ and $\mathrm{H}_{2} \mathrm{O}$. We used a BC RI of 1.95-0.79i (upper bound) recommended by Bond and Bergstrom (2006) and a BC density of $1.77 \mathrm{~g} \mathrm{~cm}^{-3}$ suggested by Zhang et al. (2008). Under the preceding conditions, computations of $\mathrm{BC}$ optical properties at $532 \mathrm{~nm}$ wavelength were carried out for comparison with laboratory measurements. The comparison between GOS and experimental results in this study provides an additional dimension of validation/cross-check of the GOS approach.

In addition, we conducted four sensitivity calculations for Stage I and six sensitivity calculations for Stages II and III to quantify uncertainties associated with BC RI and morphology (see Table 1). In the first sensitivity calculation for each aging stage, a lower bound of BC RI of 1.75-0.63i recommended by Bond and Bergstrom (2006) was used. For the other three sensitivity tests on morphology effects at Stage I, we increased $\mathrm{BC}$ fractal dimension from 2.1 to 2.5 and primary spherules diameter from 15 to $20 \mathrm{~nm}$ without changing $\mathrm{BC}$ mass, and replaced $\mathrm{BC}$ aggregates with a single volumeequivalent sphere. We then applied five types of BC coating structures, including off-center core-shell, closed-cell, opencell, partially encapsulated, and externally attached structures (see Fig. 1 and Sect. 2.1), and conducted five additional sensitivity calculations for both Stages II and III. Specifically, the off-center core-shell structure assumes a spherical BC core internally tangent to the particle surface with the same size as the concentric core-shell structure used in standard calculations. The closed-cell structure assumes that all primary spherules have the same concentric core-shell shape with a BC core diameter of $15 \mathrm{~nm}$. The open-cell structure also assumes a diameter of $15 \mathrm{~nm}$ for all primary spherules, which are either pure $\mathrm{BC}$ or pure coating material. Both closed- and open-cell structures were constructed to have the same fractal dimension as measured in the experiments. The partially encapsulated structure assumes that a random part of $\mathrm{BC}$ aggregates is inside a spherical coating particle (Figs. S1-S6), while the externally attached structure assumes that a single spherical coating particle is randomly sticking to a part of the BC aggregate's surface (Figs. S1S6). BC primary spherules in both structures have diameters of $15 \mathrm{~nm}$. We note that assuming a cluster of spheres for the above-mentioned coating structures may not be sufficiently realistic and that nonspherical morphology models without restrictions to composite of spheres appear to be more plausible (Adachi et al., 2010), a challenging subject to be investigated in future work. 


\section{Results and discussions}

\subsection{Fresh BC aggregates (Stage I)}

Figure 3 shows the extinction, absorption, and scattering cross sections (at $532 \mathrm{~nm}$ ) of fresh BC aggregates at Stage I based on laboratory measurements and theoretical calculations using different BC RI and morphology. For comparison with experimental measurements, theoretical results with BC RI of 1.95-0.79i (i.e., standard calculations) are used unless stated otherwise. The calculated extinction cross sections are consistent (differences $\leq 20 \%$ ) with measurements for fresh BC aggregates at Stage I with different sizes (i.e., $D_{\mathrm{BC}}=155,245$, and $320 \mathrm{~nm}$ ). However, theoretical calculations tend to overestimate and underestimate extinction for the smallest and largest $\mathrm{BC}$ aggregates, respectively. The discrepancies between theoretical and measured BC absorption cross sections at Stage I increase from $7 \%$ (overestimate) to $-15 \%$ (underestimate) as $\mathrm{BC}$ size becomes larger (Fig. 3). Although the calculated scattering cross sections at Stage I are consistently overestimated for different BC sizes compared with measurements, the absolute discrepancies are small. This overestimate is partly because of the uncertainty associated with extinction and absorption calculations for small particles, where theoretical results overestimate (underestimate) extinction cross sections more (less) than absorption cross sections for $D_{\mathrm{BC}}$ of $155 \mathrm{~nm}$ ( $D_{\mathrm{BC}}$ of 245 and $320 \mathrm{~nm}$ ). The scattering measurements also contribute to the discrepancy in view of the fact that the integrating nephelometer misses light scattering signals at nearforward directions (Anderson and Ogren, 1998). We note that the calculated single scattering albedo (SSA; 0.16) of BC aggregates at Stage I is within the range of $0.15-0.3$ measured for $\mathrm{BC}$ from different combustion sources (Bond and Bergstrom, 2006), while the experimentally measured SSA is smaller than 0.10 due to the relatively open and loosely connected BC aggregate structures (Khalizov et al., 2009a).

Sensitivity calculations show that using a BC RI of 1.75$0.63 i$ narrows the gap between calculated and measured scattering cross sections of fresh $\mathrm{BC}$ aggregates by up to a factor of 2 (Fig. 3). Because of using the BC RIs of 1.95-0.79i (upper bound) and 1.75-0.63i (lower bound), the extinction and absorption cross sections of fresh $\mathrm{BC}$ aggregates can vary by $25-40 \%$ and $20-30 \%$, respectively, while the scattering cross section ranges from 50 to $65 \%$ with a higher sensitivity for larger BC sizes. Based on the T-matrix calculations using a BC RI of 2-1i and 1.75-0.5i, Liu et al. (2008) showed variation of 50-70\% in BC absorption and scattering cross sections depending on aggregate structures, which is comparable to the results derived in this study. Scarnato et al. (2015) also found a strong dependence of BC absorption on BC RI for uncoated aggregates using the DDA method.

Figure 4 shows the extinction, absorption, and scattering cross sections for different aggregate morphology normalized by $\mathrm{BC}$ aggregate cross sections determined from standard calculations (i.e., fractal aggregates with a $D_{\mathrm{f}}$ of 2.1 and $D_{\mathrm{p}}$ of $15 \mathrm{~nm}$; see Sect. 2.4) at Stage I. We found that a $20 \%$ increase in $D_{\mathrm{f}}$ (i.e., more compact structure) decreases $\mathrm{BC}$ absorption and scattering cross sections by 20-50\%, with greater reductions for larger BC sizes. Using the DDA method, Scarnato et al. (2013) also found a smaller BC absorption of more compact structures. Liu et al. (2008) applied a T-matrix calculation to show that as $D_{\mathrm{f}}$ increases from 1.5 to 3 , the absorption of $\mathrm{BC}$ aggregates either decreases monotonically or decreases until $D_{\mathrm{f}}$ reaches a certain value and then increases, depending on BC RI, size and the number of primary spherules. This is because the amount of $\mathrm{BC}$ directly exposed to the incident light becomes smaller as $D_{\mathrm{f}}$ increases, while the growing interaction among primary spherules could increase light absorption (Liu et al., 2008). The present calculations illustrated that $\mathrm{BC}$ absorption and scattering are weakly dependent on the size of primary $\mathrm{BC}$ spherules. An increase in the spherule diameter from 15 to $20 \mathrm{~nm}$ results in less than $10 \%$ variation in BC extinction, absorption, and scattering cross sections (Fig. 4), which is consistent with the $\mathbf{T}$-matrix results presented by Liu and Mishchenko (2007) who concluded that the monomer size has a rather weak effect on BC scattering and absorption, if fractal dimension is fixed. Nevertheless, the effect of monomer size on BC optical properties could vary significantly depending on $\mathrm{BC}$ aggregate shape, size, the number of primary spherules, and BC RI (Liu et al., 2008; Kahnert et al., 2014). Assuming a volume-equivalent BC sphere instead of fractal aggregates results in 5-25\% weaker absorption and extinction and up to $65 \%$ smaller scattering cross sections for different $\mathrm{BC}$ sizes, compared with $\mathrm{BC}$ aggregates in standard calculations. The stronger absorption and scattering from aggregate structures is due primarily to the interaction between neighboring primary spherules of BC aggregates (Fuller, 1995). The present calculated increase (5-20\%) in absorption from sphere to aggregate structures is slightly smaller than the value $(\sim 30 \%)$ reported by Bond and Bergstrom (2006), because of different numbers and sizes of primary spherules, aggregate shapes, and fractal dimensions employed in calculations (Iskander et al., 1991; Liu et al., 2008; Kahnert et al., 2014). Using the T-matrix method, Kahnert and Devasthale (2011) showed a radiative forcing of $\mathrm{BC}$ aggregates that was 2 times higher than the volume-equivalent sphere counterparts.

\subsection{Coated BC particles (Stages II and III)}

The extinction, absorption, and scattering cross sections (at $532 \mathrm{~nm}$ ) of coated BC particles at aging Stages II and III determined from laboratory measurements and theoretical calculations are depicted in Fig. 3. Theoretical results with the BC RI of 1.95-0.79i are used for comparison with experimental measurements unless stated otherwise. The calculated optical cross sections (i.e., extinction, absorption, and scattering) of coated BC at Stages II and III are in gen- 


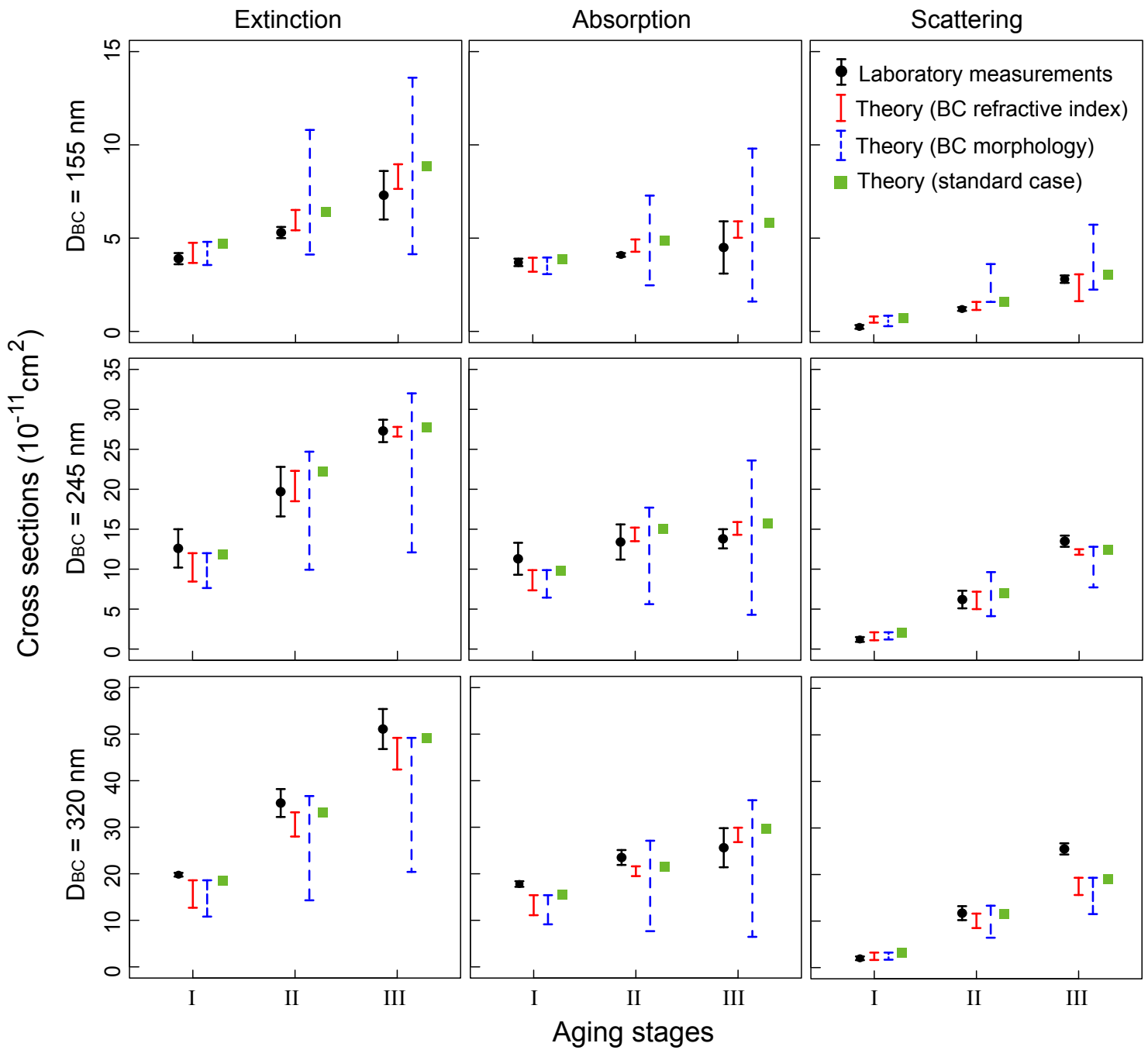

Figure 3. Laboratory measurements and theoretical calculations of BC extinction (left column), absorption (middle column), and scattering (right column) cross sections (at $532 \mathrm{~nm}$ ) at three aging stages for BC with initial mobility diameters $\left(D_{\mathrm{BC}}\right)$ of $155 \mathrm{~nm}$ (top row), $245 \mathrm{~nm}$ (middle row), and $320 \mathrm{~nm}$ (bottom row). Black circles represent mean values from measurements and black error bars indicate experimental uncertainties reported by Zhang et al. (2008) and Khalizov et al. (2009a). Green squares indicate results from the standard theoretical calculations (see Table 1 for details). Red error bars indicate the range of theoretical calculations using a BC refractive index of $1.95-0.79 i$ (upper bound) and 1.75-0.63i (lower bound). Blue error bars represent the upper and lower bounds of sensitivity calculations using different BC morphology with a refractive index of 1.95-0.79i (see also Fig. 1 and Table 1).

eral agreement (differences $\leq 30 \%$ ) with laboratory measurements, because of the observed efficient structure compaction during aging in laboratory experiments (Zhang et al., 2008). However, theoretical calculations tend to overestimate extinction and absorption for $D_{\mathrm{BC}}$ of 155 and $245 \mathrm{~nm}$ at both Stages II and III, while the extinction and absorption for the largest particle ( $D_{\mathrm{BC}}$ of $320 \mathrm{~nm}$ ) is underestimated at Stage II. The calculated scattering cross sections are overestimated for the smallest BC size $\left(D_{\mathrm{BC}}\right.$ of $\left.155 \mathrm{~nm}\right)$ at Stage II, but tend to be underestimated for larger BC sizes at Stage III, particularly for $D_{\mathrm{BC}}$ of $320 \mathrm{~nm}$. The present sensitivity calculations show that the discrepancy in scattering for $D_{\mathrm{BC}}$ of $320 \mathrm{~nm}$ at Stage III cannot be explained by uncertainties as- sociated with BC RI or coating morphology (Fig. 3), which, however, could be attributed to uncertainty associated with the coating mass of $\mathrm{H}_{2} \mathrm{SO}_{4}$ and $\mathrm{H}_{2} \mathrm{O}$. We assumed only $\mathrm{H}_{2} \mathrm{O}$ condensation during $\mathrm{BC}$ hygroscopic growth from Stage II to III in the calculation of coating mass, which may not be accurate considering that $\mathrm{H}_{2} \mathrm{SO}_{4}$ condenses on $\mathrm{BC}$ surface simultaneously along with $\mathrm{H}_{2} \mathrm{O}$. A sensitivity calculation shows that replacing $\mathrm{H}_{2} \mathrm{O}$ by $\mathrm{H}_{2} \mathrm{SO}_{4}$ in the coating material reduces scattering discrepancy to $10 \%$ for $D_{\mathrm{BC}}$ of $320 \mathrm{~nm}$ at Stage III, since $\mathrm{H}_{2} \mathrm{SO}_{4}$ is more reflective than $\mathrm{H}_{2} \mathrm{O}$, but increases the overestimate in $\mathrm{BC}$ absorption from 17 to $25 \%$.

Theoretical calculations show that using a BC RI of 1.75$0.63 i$ decreases extinction and absorption cross sections of 


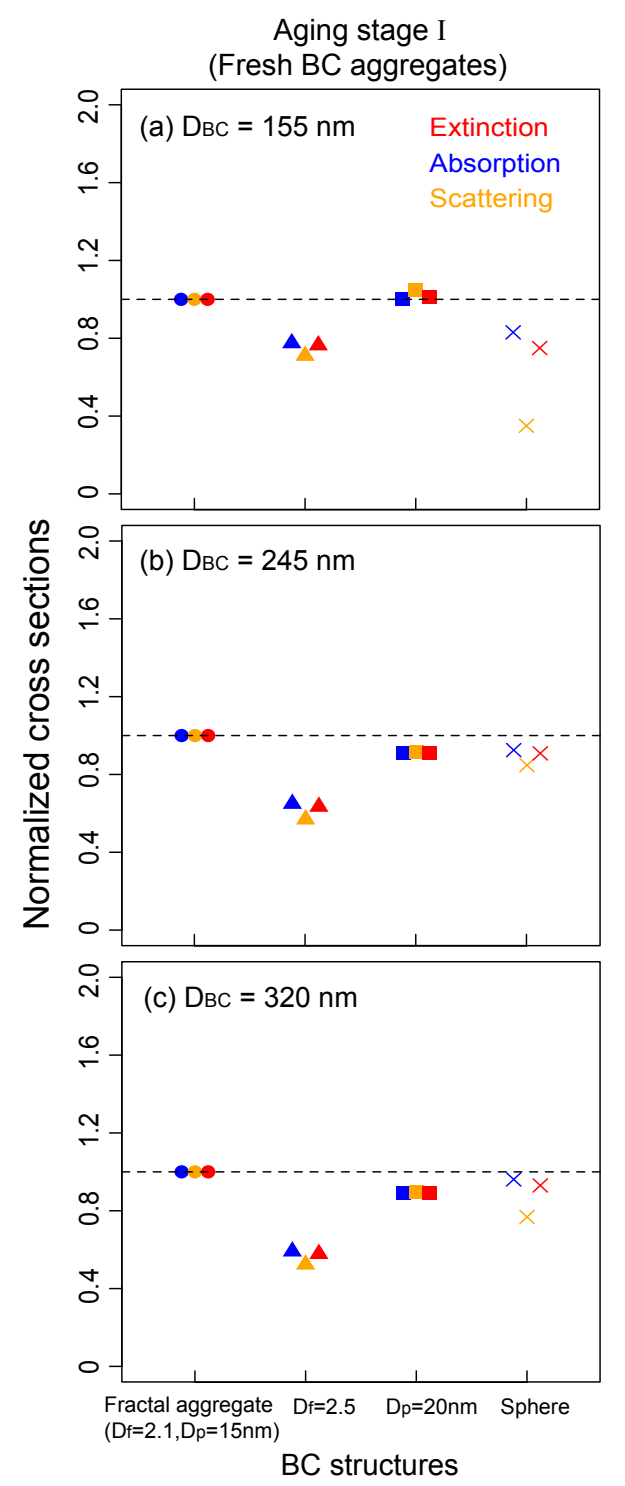

Figure 4. Extinction (red), absorption (blue), and scattering (orange) cross sections (at $532 \mathrm{~nm}$ ) for different BC morphology normalized by $\mathrm{BC}$ aggregate cross sections determined from standard calculations at aging Stage I for initial BC mobility diameters $\left(D_{\mathrm{BC}}\right)$ of $155 \mathrm{~nm}(\mathbf{a}), 245 \mathrm{~nm}$ (b), and $320 \mathrm{~nm}$ (c). Results for four $\mathrm{BC}$ structures are shown, including $\mathrm{BC}$ aggregates in standard calculations (circles) with a fractal dimension $\left(D_{\mathrm{f}}\right)$ of 2.1 and a primary spherule diameter $\left(D_{\mathrm{p}}\right)$ of $15 \mathrm{~nm}, \mathrm{BC}$ aggregates with $D_{\mathrm{f}}$ of 2.5 (triangles; versus 2.1 in standard calculations), BC aggregates with a $D_{\mathrm{p}}$ of $20 \mathrm{~nm}$ (squares; versus $15 \mathrm{~nm}$ in standard calculations), and a single mass-equivalent $\mathrm{BC}$ sphere (crosses; versus fractal aggregate in standard calculations). Dashed horizontal lines indicate a value of 1 .

coated BC particles by $10-17 \%$ at Stage II and by $5-15 \%$ at Stage III for different BC sizes, which, however, is smaller compared with the decrease for fresh $\mathrm{BC}$ aggregates (20$40 \%)$. The scattering cross sections of coated BC particles decrease by up to $50 \%$ due to the use of smaller BC RI for different $\mathrm{BC}$ sizes and aging stages.

Figures 5 and 6 show the extinction, absorption, and scattering cross sections for different coated BC structures normalized by cross sections of the concentric core-shell structure determined from standard calculations. The off-center core-shell structure has little impact on BC optical properties at Stage II (Fig. 5) with differences of less than $10 \%$ compared with the concentric core-shell structure, primarily because of the thin coating layer. As the coating thickness increases after hygroscopic growth, the off-center core-shell structure results in a 5-30\% decrease in extinction, absorption, and scattering cross sections at Stage III (Fig. 6). This finding is consistent with the result presented by Adachi et al. (2010) using the DDA method, where they found up to $30 \%$ reductions in $\mathrm{BC}$ absorption depending on the position of BC core inside coating material. A recent $\mathbf{T}$-matrix study (Mishchenko et al., 2014) also showed that the absorption of $\mathrm{BC}$-water mixture tends to decrease as a $\mathrm{BC}$ particle moves from the droplet center to the boundary.

Compared with the concentric core-shell structure, the closed-cell structure tends to have stronger absorption and weaker scattering for $D_{\mathrm{BC}}$ of 245 and $320 \mathrm{~nm}$ at Stages II and III, while the reverse is true for the open-cell structure (Figs. 5 and 6). This is in line with the conclusion presented in Liou et al. (2011) that closed-cell aggregates have larger absorption and smaller SSA than their open-cell counterparts. The closed-cell structure has a larger surface area for the interaction of the incident light with each primary spherule that acts as a coated core-shell unit, leading to a stronger lensing effect and thus stronger absorption compared with the concentric core-shell structure. However, the open-cell structure lacks a closed coating structure to produce efficient lensing effects. The coating spherules sticking to pure $\mathrm{BC}$ spherules in the open-cell structure increase the interaction between the incident light and nonabsorbing coating material, resulting in a stronger scattering.

The extinction and absorption cross sections of partially encapsulated and externally attached structures are consistently lower than those of the concentric core-shell structure by $30-80 \%$ for different BC sizes (Figs. 5 and 6). This is because the relatively open coating structure leads to inefficient lensing effect for partially encapsulated and externally attached structures, in which a part of BC aggregates is shielded from interaction with incident photons that are backscattered by the attached nonabsorbing coating material. Adachi et al. (2010) showed that the concentric coreshell structure has a 20-30\% stronger absorption than BC aggregates that are fully embedded within host sulfate. Thus, the partially encapsulated structure with only a part of BC aggregates embedded inside coating material in the present study could further decrease the absorption and lead to much smaller absorption values than a concentric core-shell structure. Kahnert et al. (2013) found that the difference in BC absorption between concentric core-shell and encapsulated 


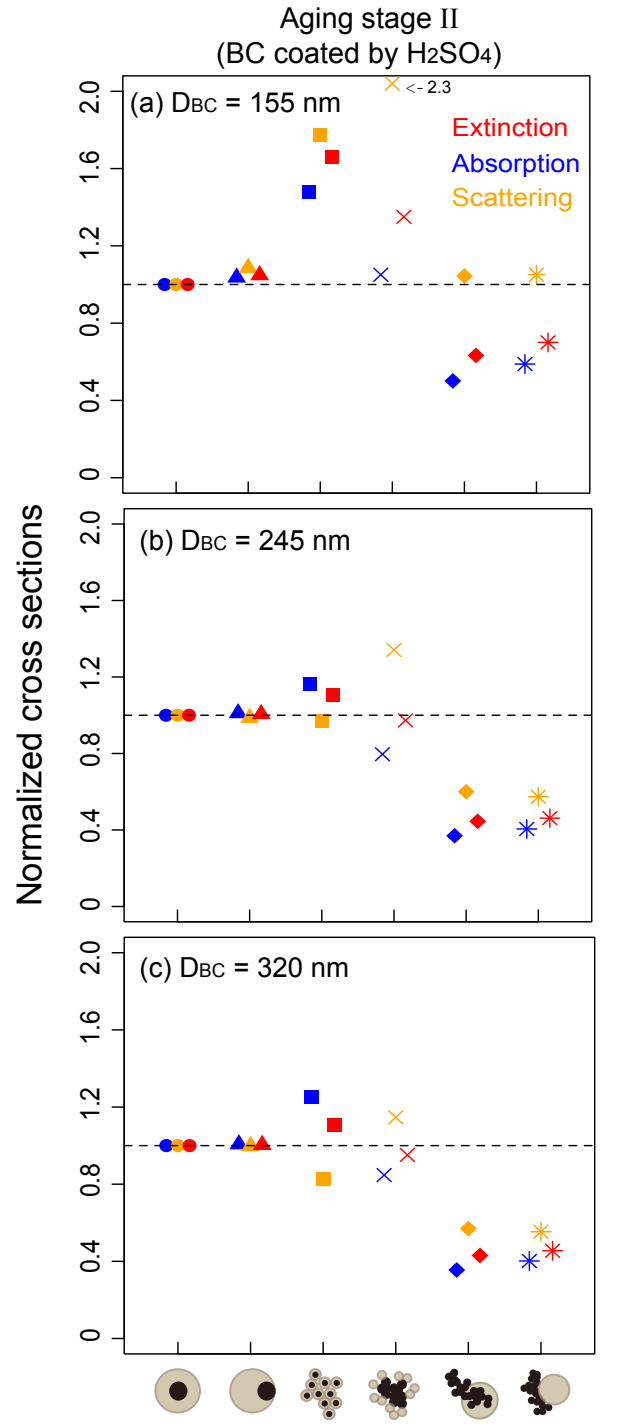

Figure 5. Extinction (red), absorption (blue), and scattering (orange) cross sections (at $532 \mathrm{~nm}$ ) for different coating morphology normalized by cross sections of concentric core-shell structures determined from standard calculations at aging Stage II (BC coated by sulfuric acid $\left.\left(\mathrm{H}_{2} \mathrm{SO}_{4}\right)\right)$ for initial $\mathrm{BC}$ mobility diameters $\left(D_{\mathrm{BC}}\right)$ of $155 \mathrm{~nm}(\mathbf{a}), 245 \mathrm{~nm}$ (b), and $320 \mathrm{~nm}$ (c). Six BC coating structures are considered, including concentric core-shell (circles), off-center core-shell (triangles), closed-cell (squares), opencell (crosses), partly encapsulated (diamonds), and externally attached (asterisks) structures (see also Fig. 1). Dashed horizontal lines indicate a value of 1 .

structures strongly depends on particle size, $\mathrm{BC}$ volume fraction, and wavelength, based on the DDA calculation. Interestingly, we found that the absorption of partially encapsulated structure is $10-40 \%$ weaker than that of externally attached structure with larger differences for thicker coating, while their scattering cross sections are similar (differences $\leq 5 \%$ ). The preceding analysis demonstrates that coating structures

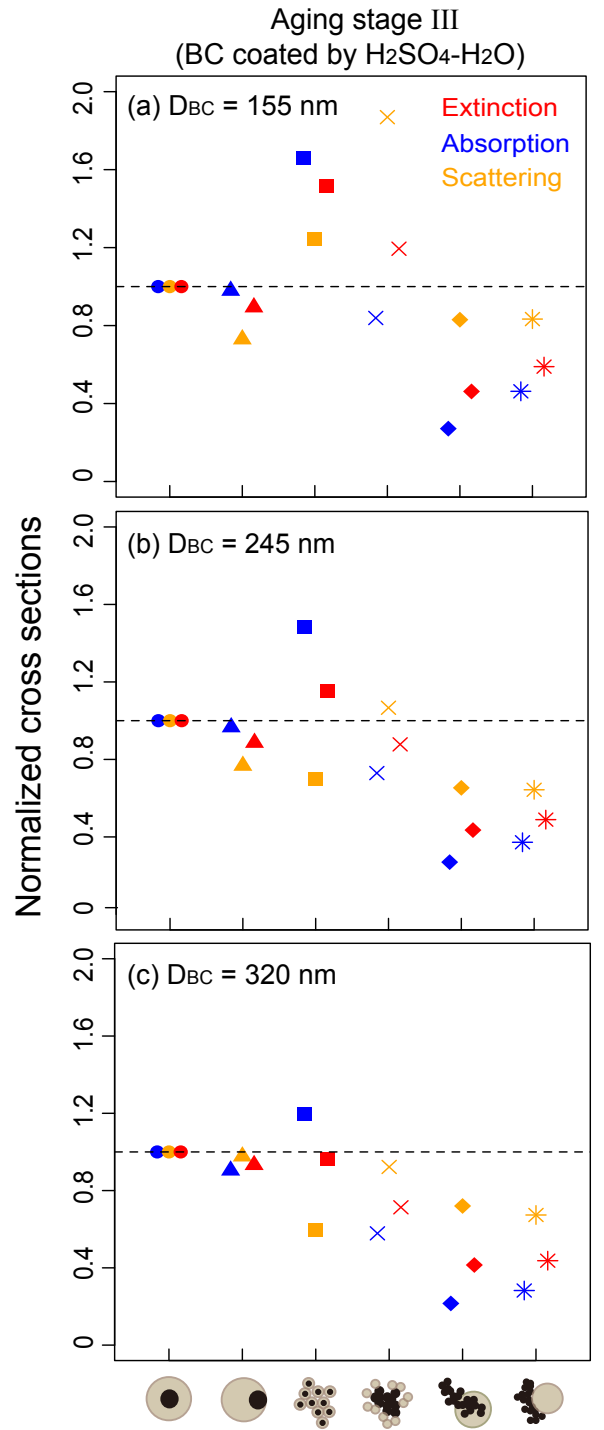

Figure 6. Same as Fig. 5, but for aging stage III where BC particles are coated by both sulfuric acid and water $\left(\mathrm{H}_{2} \mathrm{SO}_{4}-\mathrm{H}_{2} \mathrm{O}\right)$.

exert a significant impact on BC optical properties. Thus, in order to produce reliable and accurate estimates of $\mathrm{BC}$ radiative forcing in climate models, the development of a realistic $\mathrm{BC}$ coating morphology parameterization appears to be essential, which, however, could be a challenging task in view of limited observations available at the present time.

\subsection{Evolution of BC absorption and scattering}

Figure 7 shows the enhancement in absorption and scattering during $\mathrm{BC}$ aging from freshly emitted aggregates (Stage I) to $\mathrm{BC}$ coated by $\mathrm{H}_{2} \mathrm{SO}_{4}$ (Stage II) and by $\mathrm{H}_{2} \mathrm{SO}_{4}-\mathrm{H}_{2} \mathrm{O}$ (Stage III) for different $\mathrm{BC}$ coating structures and sizes. The measured $\mathrm{BC}$ absorption increases by $10-45 \%$ due to coating, while the concentric core-shell model results in a 20 $65 \%$ absorption increase depending on $\mathrm{BC}$ sizes and aging 


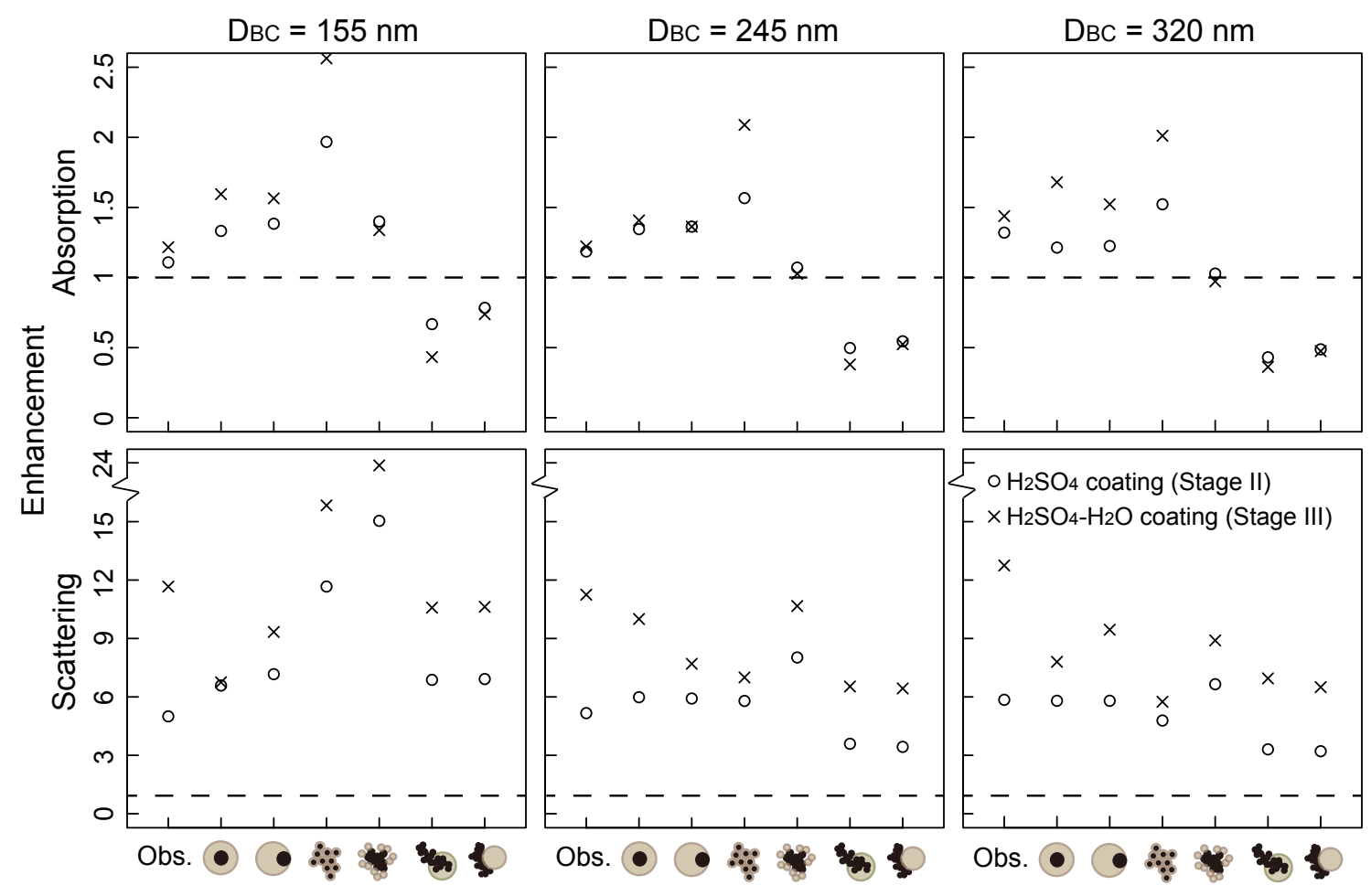

Figure 7. Enhancement in BC absorption (top) and scattering (bottom) during aging from freshly emitted aggregates at Stage I to BC coated by sulfuric acid $\left(\mathrm{H}_{2} \mathrm{SO}_{4}\right)$ at Stage II (circles), and by both sulfuric acid and water $\left(\mathrm{H}_{2} \mathrm{SO}_{4}-\mathrm{H}_{2} \mathrm{O}\right)$ at Stage III (crosses) for initial BC mobility sizes $\left(\mathrm{D}_{B C}\right)$ of $155 \mathrm{~nm}$ (left), $245 \mathrm{~nm}$ (middle), and $320 \mathrm{~nm}$ (right). The enhancements for different BC coating morphology are shown, including concentric core-shell, off-center core-shell, closed-cell, open-cell, partly encapsulated, and externally attached structures (see also Fig. 1). The reference case for enhancement calculation is the fresh $\mathrm{BC}$ aggregate measured in laboratory experiments, which is used for all six $\mathrm{BC}$ coating morphology cases. Thus, the enhancement is computed as the ratio of calculated absorption/scattering cross sections of coated BC particles to observed values of fresh BC aggregates. Also shown is the measured enhancement from laboratory experiments (Obs.). Horizontal dashed lines indicate a value of 1.0.

stages. This implies that assuming a concentric core-shell shape could overestimate $\mathrm{BC}$ radiative forcing. Adachi et al. (2010) found that using a more realistic BC coating morphology from field measurements leads to about $20 \%$ less BC DRF than using a concentric core-shell shape.

Moreover, coated BC particles with closed-cell structures enhance absorption by $50-100 \%$ for Stage II and more than $100 \%$ after hygroscopic growth (Fig. 7). In contrast, the open-cell structures produce less than $10 \%$ increase in absorption during aging for $D_{\mathrm{BC}}$ of 245 and $320 \mathrm{~nm}$, while the enhancement tends to be stronger for smaller BC size $\left(D_{\mathrm{BC}}=155 \mathrm{~nm}\right)$. Surprisingly, we found that the partially encapsulated and externally attached $\mathrm{BC}$ structures have a weaker absorption than fresh $\mathrm{BC}$ aggregates, probably because that the two structures in the absence of fully embedded shape have no efficient lensing effect and that the nonabsorbing coating material blocks the photons coming from behind BC aggregates and produces a shadowing effect (Liu and Mishchenko, 2007). This shadowing effect could also explain the decreasing BC absorption for partially encapsulated, externally attached, and open-cell structures when coating material increases during Stages II to III. Adachi and Buseck (2013) and Scarnato et al. (2013) found that BC particles attached to or partially immersed in host material, instead of fully embedded within them, do not show noticeable increases in $\mathrm{BC}$ absorption relative to uncoated aggregates based on DDA calculations. Bond et al. (2006) recommended a $50 \%$ increase in $\mathrm{BC}$ absorption to account for the averaged coating effect during atmospheric aging. However, in light of the preceding analysis, the morphology, composition, and amount of coating play significant roles in altering the BC optical properties during aging. It appears that a fixed enhancement factor may not represent the realistic increase in $\mathrm{BC}$ absorption due to complex coating, particularly over regions with highly heterogeneous aging conditions.

Compared with absorption enhancement, $\mathrm{BC}$ coating results in a much larger increase in scattering, with a greater enhancement for a larger amount of coating material (Fig. 7). The measured scattering cross sections from laboratory experiments for different $\mathrm{BC}$ sizes increase by a factor of 5-6 from Stage I to II and a factor of 11-13 from Stage I to III. Theoretical calculations show that the increase in scattering 
from Stage I to II varies from a factor of 3 to 8 for $D_{\mathrm{BC}}$ of 245 and $320 \mathrm{~nm}$ depending on coating morphology, while both the magnitude and variation of enhancement are much larger for $D_{\mathrm{BC}}$ of $155 \mathrm{~nm}$ ranging from a factor of 6 to 15 . After hygroscopic growth (Stage III), BC scattering further increases by 20-200\% for different coating structures relative to that at Stage II. Cheng et al. (2009) observed that the increase in BC scattering, due to both the increased amount of coating and the transition of uncoated to coated BC, can reach up to a factor of 8-10 within several hours' aging at a polluted site in northeastern China, which is comparable to laboratory measurements and theoretical calculations presented above.

\section{Atmospheric implications}

Our theoretical calculations have shown that BC absorption and scattering are highly sensitive to coating morphology and the amount of coating at different aging stages. This suggests that the change of BC coating states (e.g., coating thickness, morphology, and composition) during the aging process in the real atmosphere could substantially affect BC radiative properties and thus its climatic effects. Metcalf et al. (2012) observed that the mean BC coating thickness increases from $\sim 95 \mathrm{~nm}$ over urban areas within boundary layers to $\sim 150 \mathrm{~nm}$ in its downwind regions and $\sim 190 \mathrm{~nm}$ in the free troposphere, with number fractions of thickly coated BC in the free troposphere and downwind regions higher than near the source by a factor of 2. Such large variations in BC coating thickness and number fraction of thickly coated BC during aging have also been observed over the tropics from the ground to high altitudes (Schwarz et al., 2008), implying a strong dependence of $\mathrm{BC}$ coating state on aging condition and timescale that $\mathrm{BC}$ particles have experienced. Furthermore, atmospheric observations also suggest large variability in the composition of coating materials (Moteki et al., 2007; Metcalf et al., 2012) and coating morphology (China et al., 2013, 2015) during BC aging under different atmospheric conditions. Thus, better characterizations of BC coating mass, composition, and morphology during aging are critically important to accurately estimate $\mathrm{BC}$ radiative effects.

However, many global models tend to use fixed BC optical properties or simplified core-shell models for the computation of BC radiative effects (Bond et al., 2013), which may not be representative and sufficiently accurate in view of various $\mathrm{BC}$ coating states in the real atmosphere. This study suggests that a reliable estimate of $\mathrm{BC}$ radiative effects in climate models would require the representation of a dynamic $\mathrm{BC}$ aging process with realistic coating structures, especially for regional analysis with highly heterogeneous atmospheric conditions.

\section{Conclusions}

We developed a theoretical model that accounts for three typical BC aging stages, including freshly emitted aggregates, $\mathrm{BC}$ coated by soluble material, and coated BC particles after further hygroscopic growth. The GOS approach was used to compute $\mathrm{BC}$ absorption and scattering at each aging stage, which was coupled with a stochastic procedure to construct different BC structures. The theoretical calculations were compared with laboratory measurements, followed by a systematic analysis of uncertainties associated with BC RI and morphology. Finally, we discussed atmospheric implications of our results in the assessment of $\mathrm{BC}$ radiative effects.

Theoretical calculations yielded consistent extinction (sum of absorption and scattering) cross sections for fresh BC aggregates at Stage I, with differences of less than $20 \%$ compared with measurements. Theoretical calculations underestimated $\mathrm{BC}$ absorption by up to $25 \%$, while overestimated BC scattering for different sizes, because of uncertainties associated with both theoretical calculations for small particles and scattering measurements in laboratory experiments. Sensitivity calculations showed that variation of the extinction and absorption cross sections of fresh BC aggregates is $20-40 \%$ due to the use of upper and lower bounds of BC RIs, while variation of the scattering cross section ranges from 50 to $65 \%$ with a higher sensitivity for larger BC sizes. We also found that the optical cross sections of BC aggregates are sensitive to fractal dimension, but insensitive to the size of primary spherules. Using volume-equivalent spheres instead of aggregates decreased the BC absorption at Stage I.

The measured extinction, absorption, and scattering cross sections of coated BC were generally captured (differences $\leq 30 \%$ ) by theoretical calculations using a concentric core-shell structure for Stages II and III. However, theoretical calculations tend to overestimate extinction and absorption for $D_{\mathrm{BC}}$ of 155 and $245 \mathrm{~nm}$ at Stages II and III, while the scattering tends to be underestimated for larger BC sizes at Stage III, particularly for $D_{\mathrm{BC}}$ of $320 \mathrm{~nm}$ due partly to the uncertainty associated with $\mathrm{H}_{2} \mathrm{SO}_{4}-\mathrm{H}_{2} \mathrm{O}$ coating mass. Sensitivity analyses showed that the effects of BC RI on extinction and absorption for coated $\mathrm{BC}$ were much smaller than that for fresh BC aggregates. The off-center core-shell structure resulted in up to $30 \%$ less absorption and scattering cross sections than the concentric core-shell structure. The opencell structure tended to have weaker absorption and stronger scattering than the concentric core-shell structure, while the reverse is true for the closed-cell structure. Compared with the concentric core-shell structure, the partially encapsulated and externally attached structures had substantially smaller absorption and scattering cross sections due to the lack of efficient lensing effects.

Theoretical calculations showed that using a concentric core-shell structure overestimated the measured enhancement in $\mathrm{BC}$ absorption by up to $30 \%$ during aging. The closed-cell structure led to increases in $\mathrm{BC}$ absorption higher 
than measured values by a factor of 2 , while the open-cell structure did not show a noticeable increase in absorption for $D_{\mathrm{BC}}$ of 245 and $320 \mathrm{~nm}$ during aging. The partially encapsulated and externally attached coating structures had a weaker absorption than fresh $\mathrm{BC}$ aggregates, likely produced by the shadowing effect from nonabsorbing coating material as well as the lack of efficient lensing effect. The increase in BC scattering during aging was much stronger than absorption, ranging from a factor of 3 to 24 depending on BC size, morphology, and aging stage. Thus, the present analysis showed that $\mathrm{BC}$ optical properties are highly sensitive to BC morphology and coating mass at different aging stages.

Our theoretical calculations suggested that the evolution of $\mathrm{BC}$ coating states (e.g., coating thickness, morphology, and composition) during aging in the real atmosphere could exert significant impacts on $\mathrm{BC}$ radiative properties and thus its climatic effects, particularly over regions with high heterogeneity. Therefore, to accurately estimate $\mathrm{BC}$ radiative effects requires the incorporation of a dynamic $\mathrm{BC}$ aging process accounting for realistic coating structures in climate models.

\section{The Supplement related to this article is available online at doi:10.5194/acp-15-11967-2015-supplement.}

Acknowledgements. This research was supported by the NSF under grant AGS-0946315 and AGS-1523296, by the DOE Earth System Modeling program under grant DESC0006742, and by subcontract S100097 from the Texas A\&M Research Foundation, which is sponsored by NASA under grant NNX11AK39G. Pacific Northwest National Laboratory is operated for DOE by Battelle Memorial Institute under contract DE-AC05-76RL01830. R. Zhang acknowledges the support by the Robert A. Welch Foundation (A-1417). Users can access the data in this study through the corresponding author.

Edited by: M. Shiraiwa

\section{References}

Adachi, K. and Buseck, P. R.: Changes of ns-soot mixing states and shapes in an urban area during CalNex, J. Geophys. Res.-Atmos., 118, 3723-3730, doi:10.1002/Jgrd.50321, 2013.

Adachi, K., Chung, S. H., and Buseck, P. R.: Shapes of soot aerosol particles and implications for their effects on climate, J. Geophys. Res.-Atmos., 115, D15206, doi:10.1029/2009jd012868, 2010.

Anderson, T. L. and Ogren, J. A.: Determining aerosol radiative properties using the TSI 3563 integrating nephelometer, Aerosol Sci. Tech., 29, 57-69, doi:10.1080/02786829808965551, 1998.

Bond, T. C. and Bergstrom, R. W.: Light absorption by carbonaceous particles: An investigative review, Aerosol Sci. Tech., 40, 27-67, doi:10.1080/02786820500421521, 2006.
Bond, T. C., Habib, G., and Bergstrom, R. W.: Limitations in the enhancement of visible light absorption due to mixing state, J. Geophys. Res.-Atmos., 111, D20211, dio:10.1029/2006jd007315, 2006.

Bond, T. C., Doherty, S. J., Fahey, D. W., Forster, P. M., Berntsen, T., DeAngelo, B. J., Flanner, M. G., Ghan, S., Karcher, B., Koch, D., Kinne, S., Kondo, Y., Quinn, P. K., Sarofim, M. C., Schultz, M. G., Schulz, M., Venkataraman, C., Zhang, H., Zhang, S., Bellouin, N., Guttikunda, S. K., Hopke, P. K., Jacobson, M. Z., Kaiser, J. W., Klimont, Z., Lohmann, U., Schwarz, J. P., Shindell, D., Storelvmo, T., Warren, S. G., and Zender, C. S.: Bounding the role of black carbon in the climate system: A scientific assessment, J. Geophys. Res.-Atmos., 118, 5380-5552, doi:10.1002/Jgrd.50171, 2013.

Born, M. and Wolf, E.: Principles of Optics: electromagnetic theory of propagation, interference and diffraction of light, 7th Edn., Cambridge University Press, UK, 636-637, 1999.

Cappa, C. D., Onasch, T. B., Massoli, P., Worsnop, D. R., Bates, T. S., Cross, E. S., Davidovits, P., Hakala, J., Hayden, K. L., Jobson, B. T., Kolesar, K. R., Lack, D. A., Lerner, B. M., Li, S. M., Mellon, D., Nuaaman, I., Olfert, J. S., Petaja, T., Quinn, P. K., Song, C., Subramanian, R., Williams, E. J., and Zaveri, R. A.: Radiative Absorption Enhancements Due to the Mixing State of Atmospheric Black Carbon, Science, 337, 1078-1081, doi:10.1126/science.1223447, 2012.

Cheng, Y. F., Berghof, M., Garland, R. M., Wiedensohler, A., Wehner, B., Muller, T., Su, H., Zhang, Y. H., Achtert, P., Nowak, A., Pöschl, U., Zhu, T., Hu, M., and Zeng, L. M.: Influence of soot mixing state on aerosol light absorption and single scattering albedo during air mass aging at a polluted regional site in northeastern China, J. Geophys. Res.-Atmos., 114, D00g10, doi:10.1029/2008jd010883, 2009.

China, S., Mazzoleni, C., Gorkowski, K., Aiken, A. C., and Dubey, M. K.: Morphology and mixing state of individual freshly emitted wildfire carbonaceous particles, Nat. Commun., 4, 2122, doi:10.1038/ncomms3122, 2013.

China, S., Scarnato, B., Owen, R. C., Zhang, B., Ampadu, M. T., Kumar, S., Dzepina, K., Dziobak, M. P., Fialho, P., Perlinger, J. A., Hueber, J., Helmig, D., Mazzoleni, L. R., and Mazzoleni, C.: Morphology and mixing state of aged soot particles at a remote marine free troposphere site: Implications for optical properties, Geophys. Res. Lett., 42, 1243-1250, doi:10.1002/2014g1062404, 2015.

Draine, B. T. and Flatau, P. J.: Discrete-Dipole Approximation for Scattering Calculations, J. Opt. Soc. Am. A, 11, 1491-1499, doi:10.1364/Josaa.11.001491, 1994.

Fuller, K. A.: Scattering and Absorption Cross-Sections of Compounded Spheres .2. Calculations for External Aggregation, J. Opt. Soc. Am. A, 12, 881-892, doi:10.1364/Josaa.12.000881, 1995.

Gangl, M., Kocifaj, M., Videen, G., and Horvath, H.: Light absorption by coated nano-sized carbonaceous particles, Atmos. Environ., 42, 2571-2581, doi:10.1016/j.atmosenv.2007.05.030, 2008.

He, C., Li, Q. B., Liou, K. N., Takano, Y., Gu, Y., Qi, L., Mao, Y. H., and Leung, L. R.: Black carbon radiative forcing over the Tibetan Plateau, Geophys. Res. Lett., 41, 7806-7813, doi:10.1002/2014g1062191, 2014. 
Heintzenberg, J.: Fine particles in the global troposphere: A review, Tellus B, 41, 149-160, doi:10.1111/j.16000889.1989.tb00132.x, 1989.

Heintzenberg, J. and Covert, D. S.: Size Distribution of Elemental Carbon, Sulfur and Total Mass in the Radius Range $10^{-6}$ to $10^{-4} \mathrm{~cm}$, Sci. Total Environ., 36, 289-297, doi:10.1016/00489697(84)90279-1, 1984

Iskander, M. F., Chen, H. Y., and Penner, J. E.: Resonance OpticalAbsorption by Fractal Agglomerates of Smoke Aerosols, Atmos. Environ., 25, 2563-2569, doi:10.1016/0960-1686(91)90173-5, 1991.

Jacobson, M. Z.: Strong radiative heating due to the mixing state of black carbon in atmospheric aerosols, Nature, 409, 695-697, doi:10.1038/35055518, 2001.

Jacobson, M. Z.: Effects of biomass burning on climate, accounting for heat and moisture fluxes, black and brown carbon, and cloud absorption effects, J. Geophys. Res.-Atmos., 119, 89809002, doi:10.1002/2014JD021861, 2014.

Johnson, K. S., Zuberi, B., Molina, L. T., Molina, M. J., Iedema, M. J., Cowin, J. P., Gaspar, D. J., Wang, C., and Laskin, A.: Processing of soot in an urban environment: case study from the Mexico City Metropolitan Area, Atmos. Chem. Phys., 5, 3033-3043, doi:10.5194/acp-5-3033-2005, 2005.

Kahnert, M. and Devasthale, A.: Black carbon fractal morphology and short-wave radiative impact: a modelling study, Atmos. Chem. Phys., 11, 11745-11759, doi:10.5194/acp-11-117452011, 2011.

Kahnert, M., Nousiainen, T., and Lindqvist, H.: Models for integrated and differential scattering optical properties of encapsulated light absorbing carbon aggregates, Opt. Express., 21, 79747993, doi:10.1364/Oe.21.007974, 2013.

Kahnert, M., Nousiainen, T., and Lindqvist, H.: Review: Model particles in atmospheric optics, J. Quant. Spectrosc. Ra., 146, 41-58, doi:10.1016/j.jqsrt.2014.02.014, 2014.

Kasper, M., Siegmann, K., and Sattler, K.: Evaluation of an in situ sampling probe for its accuracy in determining particle size distributions from flames, J. Aerosol Sci., 28, 1569-1578, doi:10.1016/S0021-8502(97)00031-1, 1997.

Khalizov, A. F., Xue, H. X., Wang, L., Zheng, J., and Zhang, R. Y.: Enhanced Light Absorption and Scattering by Carbon Soot Aerosol Internally Mixed with Sulfuric Acid, J. Phys. Chem. A, 113, 1066-1074, doi:10.1021/Jp807531n, 2009a.

Khalizov, A. F., Zhang, R. Y., Zhang, D., Xue, H. X., Pagels, J., and McMurry, P. H.: Formation of highly hygroscopic soot aerosols upon internal mixing with sulfuric acid vapor, J. Geophys. Res.Atmos., 114, D05208, doi:10.1029/2008jd010595, 2009b.

Khalizov, A. F., Cruz-Quinones, M., and Zhang, R. Y.: Heterogeneous Reaction of NO2 on Fresh and Coated Soot Surfaces, J. Phys. Chem. A, 114, 7516-7524, doi:10.1021/Jp1021938, 2010.

Knox, A., Evans, G. J., Brook, J. R., Yao, X., Jeong, C. H., Godri, K. J., Sabaliauskas, K., and Slowik, J. G.: Mass Absorption Cross-Section of Ambient Black Carbon Aerosol in Relation to Chemical Age, Aerosol Sci. Tech., 43, 522-532, doi:10.1080/02786820902777207, 2009.

Kondo, Y., Matsui, H., Moteki, N., Sahu, L., Takegawa, N., Kajino, M., Zhao, Y., Cubison, M. J., Jimenez, J. L., Vay, S., Diskin, G. S., Anderson, B., Wisthaler, A., Mikoviny, T., Fuelberg, H. E., Blake, D. R., Huey, G., Weinheimer, A. J., Knapp, D. J., and Brune, W. H.: Emissions of black carbon, organic, and inorganic aerosols from biomass burning in North America and Asia in 2008, J. Geophys. Res.-Atmos., 116, D08204, doi:10.1029/2010jd015152, 2011.

Lack, D. A., Langridge, J. M., Bahreini, R., Cappa, C. D., Middlebrook, A. M., and Schwarz, J. P.: Brown carbon and internal mixing in biomass burning particles, P. Natl. Acad. Sci. USA, 109, 14802-14807, doi:10.1073/pnas.1206575109, 2012.

Liou, K. N., Takano, Y., and Yang, P.: On geometric optics and surface waves for light scattering by spheres, J. Quant. Spectrosc. Ra., 111, 1980-1989, doi:10.1016/j.jqsrt.2010.04.004, 2010.

Liou, K. N., Takano, Y., and Yang, P.: Light absorption and scattering by aggregates: Application to black carbon and snow grains, J. Quant. Spectrosc. Ra., 112, 1581-1594, doi:10.1016/j.jqsrt.2011.03.007, 2011.

Liou, K. N., Takano, Y., He, C., Yang, P., Leung, L. R., Gu, Y., and Lee, W. L.: Stochastic parameterization for light absorption by internally mixed $\mathrm{BC} /$ dust in snow grains for application to climate models, J. Geophys. Res.-Atmos., 119, 7616-7632, doi:10.1002/2014jd021665, 2014.

Liu, L. and Mishchenko, M. I.: Scattering and radiative properties of complex soot and soot-containing aggregate particles, J. Quant. Spectrosc. Ra., 106, 262-273, doi:10.1016/j.jqsrt.2007.01.020, 2007.

Liu, L., Mishchenko, M. I., and Arnott, W. P.: A study of radiative properties of fractal soot aggregates using the superposition T-matrix method, J. Quant. Spectrosc. Ra., 109, 2656-2663, doi:10.1016/j.jqsrt.2008.05.001, 2008.

Mackowski, D. W. and Mishchenko, M. I.: Calculation of the T matrix and the scattering matrix for ensembles of spheres, J. Opt. Soc. Am. A, 13, 2266-2278, doi:10.1364/Josaa.13.002266, 1996.

Martins, J. V., Artaxo, P., Liousse, C., Reid, J. S., Hobbs, P. V., and Kaufman, Y. J.: Effects of black carbon content, particle size, and mixing on light absorption by aerosols from biomass burning in Brazil, J. Geophys. Res.-Atmos., 103, 32041-32050, doi:10.1029/98jd02593, 1998.

Metcalf, A. R., Craven, J. S., Ensberg, J. J., Brioude, J., Angevine, W., Sorooshian, A., Duong, H. T., Jonsson, H. H., Flagan, R. C., and Seinfeld, J. H.: Black carbon aerosol over the Los Angeles Basin during CalNex, J. Geophys. Res.-Atmos., 117, D00v13, doi:10.1029/2011jd017255, 2012.

Mishchenko, M. I., Liu, L., Cairns, B., and Mackowski, D. W.: Optics of water cloud droplets mixed with black-carbon aerosols, Opt. Lett., 39, 2607-2610, doi:10.1364/O1.39.002607, 2014.

Moteki, N., Kondo, Y., Miyazaki, Y., Takegawa, N., Komazaki, Y., Kurata, G., Shirai, T., Blake, D. R., Miyakawa, T., and Koike, M.: Evolution of mixing state of black carbon particles: Aircraft measurements over the western Pacific in March 2004, Geophys. Res. Lett., 34, L11803, doi:10.1029/2006g1028943, 2007.

Naoe, H., Hasegawa, S., Heintzenberg, J., Okada, K., Uchiyama, A., Zaizen, Y., Kobayashi, E., and Yamazaki, A.: State of mixture of atmospheric submicrometer black carbon particles and its effect on particulate light absorption, Atmos. Environ., 43, 1296-1301, doi:10.1016/j.atmosenv.2008.11.031, 2009.

Nussenzveig, H. M. and Wiscombe, W. J.: Efficiency Factors in Mie Scattering, Phys. Rev. Lett., 45, 1490-1494, doi:10.1103/PhysRevLett.45.1490, 1980.

Pagels, J., Khalizov, A. F., McMurry, P. H., and Zhang, R. Y.: Processing of Soot by Controlled Sulphuric Acid and Water Conden- 
sationMass and Mobility Relationship, Aerosol Sci. Tech., 43, 629-640, doi:10.1080/02786820902810685, 2009.

Popovicheva, O. B., Persiantseva, N. M., Kireeva, E. D., Khokhlova, T. D., and Shonija, N. K.: Quantification of the Hygroscopic Effect of Soot Aging in the Atmosphere: Laboratory Simulations, J. Phys. Chem. A, 115, 298-306, doi:10.1021/Jp109238x, 2011.

Qiu, C., Khalizov, A. F., and Zhang, R. Y.: Soot Aging from OHInitiated Oxidation of Toluene, Environ. Sci. Technol., 46, 94649472, doi:10.1021/Es301883y, 2012.

Ramanathan, V. and Carmichael, G.: Global and regional climate changes due to black carbon, Nat. Geosci., 1, 221-227, doi:10.1038/Ngeo156, 2008.

Saathoff, H., Naumann, K. H., Schnaiter, M., Schock, W., Mohler, O., Schurath, U., Weingartner, E., Gysel, M., and Baltensperger, $\mathrm{U}$.: Coating of soot and $\left(\mathrm{NH}_{4}\right)_{2} \mathrm{SO}_{4}$ particles by ozonolysis products of alpha-pinene, J. Aerosol Sci., 34, 1297-1321, doi:10.1016/S0021-8502(03)00364-1, 2003.

Santoro, R. J., Semerjian, H. G., and Dobbins, R. A.: Soot Particle Measurements in Diffusion Flames, Combust. Flame, 51, 203218, doi:10.1016/0010-2180(83)90099-8, 1983.

Sedlacek, A. J., Lewis, E. R., Kleinman, L., Xu, J. Z., and Zhang, Q.: Determination of and evidence for non-core-shell structure of particles containing black carbon using the Single-Particle Soot Photometer (SP2), Geophys. Res. Lett., 39, L06802, doi:10.1029/2012g1050905, 2012.

Scarnato, B. V., Vahidinia, S., Richard, D. T., and Kirchstetter, T. W.: Effects of internal mixing and aggregate morphology on optical properties of black carbon using a discrete dipole approximation model, Atmos. Chem. Phys., 13, 5089-5101, doi:10.5194/acp-13-5089-2013, 2013.

Scarnato, B. V., China, S., Nielsen, K., and Mazzoleni, C.: Perturbations of the optical properties of mineral dust particles by mixing with black carbon: a numerical simulation study, Atmos. Chem. Phys., 15, 6913-6928, doi:10.5194/acp-15-6913-2015, 2015.

Schwarz, J. P., Spackman, J. R., Fahey, D. W., Gao, R. S., Lohmann, U., Stier, P., Watts, L. A., Thomson, D. S., Lack, D. A., Pfister, L., Mahoney, M. J., Baumgardner, D., Wilson, J. C., and Reeves, J. M.: Coatings and their enhancement of black carbon light absorption in the tropical atmosphere, J. Geophys. Res.-Atmos., 113, D03203, doi:10.1029/2007jd009042, 2008.

Shiraiwa, M., Kondo, Y., Moteki, N., Takegawa, N., Miyazaki, Y., and Blake, D. R.: Evolution of mixing state of black carbon in polluted air from Tokyo, Geophys. Res. Lett., 34, L16803, doi:10.1029/2007g1029819, 2007.

Shiraiwa, M., Kondo, Y., Iwamoto, T., and Kita, K.: Amplification of Light Absorption of Black Carbon by Organic Coating, Aerosol Sci. Tech., 44, 46-54, doi:10.1080/02786820903357686, 2010.

Stratmann, F., Bilde, M., Dusek, U., Frank, G. P., Hennig, T., Henning, S., Kiendler-Scharr, A., Kiselev, A., Kristensson, A., Lieberwirth, I., Mentel, T. F., Pöschl, U., Rose, D., Schneider, J., Snider, J. R., Tillmann, R., Walter, S., and Wex, H.: Examination of laboratory-generated coated soot particles: An overview of the LACIS Experiment in November (LExNo) campaign, J. Geophys. Res.-Atmos., 115, D11203, doi:10.1029/2009jd012628, 2010 .
Strawa, A. W., Drdla, K., Ferry, G. V., Verma, S., Pueschel, R. F., Yasuda, M., Salawitch, R. J., Gao, R. S., Howard, S. D., Bui, P. T., Loewenstein, M., Elkins, J. W., Perkins, K. K., and Cohen, R.: Carbonaceous aerosol (Soot) measured in the lower stratosphere during POLARIS and its role in stratospheric photochemistry, J. Geophys. Res.-Atmos., 104, 26753-26766, doi:10.1029/1999jd900453, 1999.

Takano, Y., Liou, K. N., Kahnert, M., and Yang, P.: The single-scattering properties of black carbon aggregates determined from the geometric-optics surface-wave approach and the T-matrix method, J. Quant. Spectrosc. Ra., 125, 51-56, doi:10.1016/j.jqsrt.2013.04.006, 2013.

Toon, O. B. and Ackerman, T. P.: Algorithms for the Calculation of Scattering by Stratified Spheres, Appl. Optics, 20, 3657-3660, doi:10.1364/Ao.20.003657, 1981.

Videen, G., Ngo, D., and Chylek, P.: Effective-Medium Predictions of Absorption by Graphitic Carbon in Water Droplets, Opt. Lett., 19, 1675-1677, doi:10.1364/O1.19.001675, 1994.

Wang, Y., Khalizov, A., Levy, M., and Zhang, R. Y.: New Directions: Light absorbing aerosols and their atmospheric impacts, Atmos. Environ., 81, 713-715, doi:10.1016/j.atmosenv.2013.09.034, 2013.

Weingartner, E., Burtscher, H., and Baltensperger, U.: Hygroscopic properties of carbon and diesel soot particles, Atmos. Environ., 31, 2311-2327, doi:10.1016/S1352-2310(97)00023-X, 1997.

Xue, H. X., Khalizov, A. F., Wang, L., Zheng, J., and Zhang, R. Y.: Effects of dicarboxylic acid coating on the optical properties of soot, Phys. Chem. Chem. Phys., 11, 7869-7875, doi:10.1039/B904129j, 2009.

Yang, P. and Liou, K. N.: Finite-difference time domain method for light scattering by small ice crystals in threedimensional space, J. Opt. Soc. Am. A, 13, 2072-2085, doi:10.1364/Josaa.13.002072, 1996.

Yang, P. and Liou, K. N.: Light scattering by hexagonal ice crystals: solutions by a ray-by-ray integration algorithm, J. Opt. Soc. Am. A, 14, 2278-2289, doi:10.1364/Josaa.14.002278, 1997.

Zhang, R. Y., Khalizov, A. F., Pagels, J., Zhang, D., Xue, H. X., and McMurry, P. H.: Variability in morphology, hygroscopicity, and optical properties of soot aerosols during atmospheric processing, P. Natl. Acad. Sci. USA, 105, 10291-10296, doi:10.1073/pnas.0804860105, 2008.

Zhang, R. Y., Khalizov, A., Wang, L., Hu, M., and Xu, W.: Nucleation and Growth of Nanoparticles in the Atmosphere, Chem. Rev., 112, 1957-2011, doi:10.1021/Cr2001756, 2012.

Zuberi, B., Johnson, K. S., Aleks, G. K., Molina, L. T., and Laskin, A.: Hydrophilic properties of aged soot, Geophys. Res. Lett., 32, L01807, doi:10.1029/2004g1021496, 2005. 